\title{
Study of the occurrence and distribution of "lezer" and „Bolătău“- based toponyms in Romania and their counterparts from Poland, the Czech Republic and Slovenia
}

\author{
lonela GRĂDINARU ${ }^{1 *}$, loan IOSEP ${ }^{2}$, Joanna POCIASK-KARTECZKA ${ }^{3}$, Anton BRANCEU ${ }^{4}$ and \\ PřemysI MÁCHA \\ ${ }^{1}$ Faculty of Geography and Geology, “Al. I. Cuza” University of lași, Romania \\ 2 Department of Geography, "Ștefan cel Mare" University of Suceava, Romania \\ ${ }^{3}$ Institute of Geography and Spatial Management, Hydrology Department, Jagiellonian University, \\ Poland \\ ${ }^{4}$ National Institute of Biology, Ljubljana, Slovenia \\ ${ }^{5}$ Department of Human Geography and Regional Development, University of Ostrava, Czech Republic \\ * Correspondence to: Ionela Grădinaru, Faculty of Geography and Geology, “Al. I. Cuza” University of Iași, Romania. E-mail: \\ ionela.gradinaru@gmail.com.
}

\section{O GEOREVIEW}

\section{Article history}

Received: September 2012

Received in revised form:

November 2012

Accepted: November 2012

Available online: January

2013

\begin{abstract}
The paper aims to investigate the distribution and evolution of toponyms derivative of the words "iezer" and "bolătău" (Romanian) and their counterparts in the neighboring countries, where such homologous words/toponyms exist, i.e. Poland, the Czech Republic and Slovenia. We documented that at present the terms where the toponyms originated ("iezer"/"jezero"/"jezioro" and "bolătău"/"blato"/ "błoto") are largely regarded as archaic forms, particularly "bolătău"/ "blato"/"błoto" throughout the study area. However, toponyms based on both words are still in use in a large number of derivative variants (especially in the Slavic-speaking countries), which attest their age and relevance in the toponymical practice, albeit to a different extent and with national and regional variations in terms of occurrence. The study also indicates that, whereas the research topic requires further exploration in the shape of a quantitative approach investigation, given the complexity of toponymical studies within such an extensive area, it can be inferred that currently the vast majority of toponyms based on the two terms do not refer to water bodies, but have been transferred to other elements of the landscape.
\end{abstract}

KEY WORDS: toponyms, iezer/jezero/jezioro, bolătău/blato/ błoto, lymnonyms, occurrence, Slavic

\section{Introduction}

Our interest in this research topic concerning the occurrence and distribution of toponymic forms derivative of the words "iezer" and "bolătău" was originally sparked by previous work in the field 
of limnology, where several papers were recently published referring to lakes and other water bodies named lezer and/or Bolătău (Farcas et al., 1999; Feurdean et al., 2007; Feurdean et al., 2012; Lesenciuc et al., 2010; Mîndrescu et al. 2010a, 2010b; Mîndrescu et al., 2012). Subsequently, by researching these terms in the literature, we found that toponyms derivative of "jezero" in Slovenia and the Czech Republic and "jezioro" in Poland, as well as "blato"/"błoto"based toponyms, are not uncommon denominations for lakes and reservoirs (and, by extension, for other spatial elements).

In the case of Romania, it was documented that their occurrence is related to some ethnical and linguistic peculiarities of its eastern territory, where the vast majority of these toponyms are currently found (particularly Bolătău), i.e. the Slavic influence. Therefore, after establishing the origins and relatively broad distribution of toponyms derivative of „iezer" and "bolătău" in several neighboring Slavic-speaking countries, i.e. Poland, Slovenia and the Czech Republic, our scope has expanded to documenting the types of toponyms currently in use (limnonyms, hydronims, oiconyms etc.), as well as the extent to which these toponyms are currently connected and/or can be regarded as predictors for the presence of geomorphological features such as lakes, reservoirs or marshes. In recent years it was shown that toponymy has significant potential for predicting landscape features and possibly reconstructing past landscapes based on this range of data (Conedera et al., 2007).

\section{Data and methods}

The main data resources employed for this research topic were period documents and maps, and contemporary collections of maps (atlases) from Romania, Poland, Slovenia and the Czech Republic, which have provided valuable insight on the spatial distribution and evolution of toponyms derived from the words "iezer" and "bolătău" and their counterparts from Slavic languages, where they originated (Iordan, 1963).

Other sources of information were used, as well, consisting of either specialized comprehensive databases, such as Geonames (maintained by the Czech Office for Surveying, Mapping and Cadastre), or geographical, historical and general dictionaries and encyclopedias, which provided data on the origins and occurrence (past and present) of the two toponyms. Other sources of information consisted of several publications focusing on lakes and reservoirs which contain references to the toponyms under investigation.

The methods employed in conducting this study were heterogeneous due to the lack of comprehensive toponymical databases throughout the entire study area. In some cases, we relied mostly on the scarce data provided by period documents or atlases and encyclopedias, which are seldom exhaustive in terms of the national toponymy. However, we attempted to overcome this drawback by providing as much relevant information on the topic as possible and extracting pertinent conclusions from the available data.

\section{Results and discussions}

\subsection{Romania}

Romania is located in Central Europe and its official language is Romanian, a member of the Eastern Romance group of languages. The national territory of Romania is bordered by Ukraine 
(East Slavic language), Republic of Moldova (Romanian language, Eastern Romance group), Hungary (Hungarian-Finnish group of languages), and Serbia and Bulgaria (South Slavic languages).

The toponyms lezer and Bolătău/ Bălătău have their origins in the Romanian words "iezer" and "bolătău", which have both derived from Slavic nouns, according to various sources (Scriban, 1939; DEX, 1998). The word "iezer" (with its more archaic variations "iazer" and "ézer"), denominating a deep mountain lake, or a lake/pond, as a more general meaning, is etymologically linked to various Slavic sources, including "jezeru" (SI.), "iézero" (Bg.) and "ézero"/"ózero" (Rus.) (DEX, 1998; Scriban, 1939; Iordan, 1963). Similarly, the appellative "bolătău" (and variations "bolotău"/"bălătău") is used to denominate a pond or a puddle, often with marshy characteristics, and originates from the word "boloto" (Rus.) (Scriban, 1939).

Both terms were well-known and widely used in the Romanian language (Moldovan, 1954); however, as the language evolved, both terms have become obsolete and were progressively replaced in the common language by other words with identical or similar meaning, including "lac", "iaz", "baltă", or, in the case of high mountain lakes, by the word "tău". Although the use of the words "iezer" and "bolătău" is very infrequent nowadays in speech, a significant number of toponyms derivative of them still remain in use, particularly in the case of "iezer".

The existence of the toponym lezer has been documented as early as the $15^{\text {th }}$ century by a document from 1447 by which Ștefan cel Mare reinforced a donation from a predecessor to Moldoviţa Monastery which endowed the monastery with a property consisting of several lakes (iezere in the original text) (Moldovan, 1954).

It is likely that this toponym was originally used in low altitude marshland regions. We believe it was brought to the mountainous areas either through the old transhumant type pastoral migrations, or by monks or people working in monasteries traveling from the mountain areas to their lowland properties (often including lakes and reservoirs) received as donations from the rulers of Moldavia or Wallachia in order to supply fish stocks free of fees according to the privileges granted by the respective endowments.

Both types of migrations have been documented in the northern part of the Eastern Carpathians; e.g., the people living in the old Câmpulung settlement, located in the vicinity of the lezerul Sadovei lake, were granted the right to winter their sheep and goats (i.e. to practice transhumance) in the Moldavian lowlands ranging from lași region to Orhei (in the present day Republic of Moldova), in the floodplains of Siret, Prut and Nistru (losep, 1995).

Iordan (1963) mentions the use of the word form "ozero" for the lezerul Sadovei lake, stating that it could come from the Ukr. "ozera" (lake). This form of the toponym was most likely provided by an interlocutor of Hutsul ethnicity (people of Ukrainian heritage and language), considering the fact that a large community of Hutsuls still inhabit this area and they are thought to have owned the land property which included the lake lezer in 1785 (Grămadă, 1996). However, neither the historical documents of the old district of Câmpulung (where this form of the toponym was recorded) published by Stefanelli (1915), nor the local language or toponymy of the Romanian population in this area contain the form "ozero", and use exclusively the form "iezer" in current language and toponymy.

Iordan (1963) has inventoried nearly 20 toponymic forms belonging to this branch/family (i.e. related with the toponym lezer) on the Romanian territory. However, due to the similarity in spelling, meaning and common origin, he included this toponym and its various forms in the toponymic family of the word "iaz" (pond). 
Grămadă (1996) published a detailed study on the minor toponymy of Bucovina and identified a large number of toponyms based on the name "iezer" in this region, containing elements such as Izvorul lezerului (1762), Pârâul lezerului and Prislopul lezerului (also found in old documents in German translation, as lasero, as well as on Austrian cadastral maps from 1788, as Jasury), Pădurea lezerul (1937), Pădurea lezăr (1939), etc.

On a larger scale, it is rather difficult to assess to what extent toponyms derived from the root "iezer" are still in use nationwide, due to the fact that, as yet, there is no inventory of the minor toponymy of the Romanian territory. However, it is possible to ascertain that the toponym lezer, in a simple or derivative form or accompanied by determiners, is used as a limnonym, particularly when designating lakes located in high mountain environments within glacial cirques (e.g. lezerul Pietrosului, lezerele Buhăiescu, lezerul Berhinei, lezerul Făgăraș, lezerașul Latoriței, lezerul Mare, lezerul Mic, lezerul Parâng, lezerul Podul Giurgiului, lezerul Șurianu, lezerul Nardin, lezerul Cârpa), but also in the Romanian lowlands (lezer, lezerul Dorohoi, lezerul Mostiștei, lezerul Oltina, lezerul Gîrlița, etc.) (Moldovanu, 2005; Posea et al., 1986).

As stated previously, the toponym has also been transferred to streams connected to lakes (largely known as "iezere" in the past), as well (e.g. lezer, lezerul, Izvorul lezerului, etc.), and further on to neighboring settlements of present or even past lakes which are no longer in existence (e.g. lezereni, lezer, lezeru, lezerel, lezureni), mountains (lezeru Mare, lezeru Mic), forests (Pădurea lezerul) (Grămadă, 1996), monasteries and their properties (lezeru, in Vâlcea county), etc. Such toponyms occur throughout the hilly areas of Romania and the floodplains of Danube and its tributaries (i.e., Siret, Prut, Jijia, Bârlad, Argeş, lalomiţa); albeit, they also occur in the Eastern and Southern Carpathians.

The second toponym subject to our research, Bolătău (form used in Moinești and Suceava districts, from "bolătău"/"bolatău", another word for lake/marsh), has been found to have two other known variations: Bălătău, occurring in the districts of Bârlad and Moineşti (lordan, 1963) and Bolotău, lymnonym used in Suceava district until the late $18^{\text {th }}$ century (Moldovanu, 2005).

The Geographical Dictionary of Romania (2008), based exclusively on the data contained in the 1:100.000 scale topographic maps of Romania, without any complementary information recorded on the field or extracted from the literature, also mentions the two forms: Bălătău (limnonym, landslide-dammed lake in Nemira Mts.) and Bolătău (potamonym, left side tributary of Bistriţa river in Neamț district and village in Bacău district).

Scriban (1939) and Iordan (1963) believe the toponym Bolătău/Bălătău originated in the Slavic word "boloto" (puddle, but also marsh or silted lake evolved into a marsh). Moreover, the toponymic forms Zaboloteni (lași district) and Zaboloteni/Saboloteni (Suceava district), which are the literal Ukrainian translation of "peste baltă" (across the puddle), are also thought to be a part of the same toponymic family (Iordan, 1963). The author further mentions a toponym vaguely located in Suceava district, and we believe that it refers to the lake Bolătău located in Feredeului Mts., in Sadova commune.

The hypothesis regarding the latter location is supported by recent findings in the local documentary collections ranging from 1806 to 1939 for the territory of Sadova commune, at the border with Ruşii pe Boul village (present day Paltinul), where we have identified the following toponyms: Lăptăria de la Bolătău (probably a meadow with a temporary shelter used for breeding and grazing cattle), Bolătăul Negru (pond), Bolătăul Negru (forest), Bolătăul (place) (Ștefanelli, 1915; Grămadă, 1996). Also mentioned in the region are Dealul Bolătău (Bolătău Hill) located within the territory of Șaru Dornei commune (Grămadă, 1996), which could be linked to 
the presence of a former lake, marsh, swamp or peat bog which existed in its vicinity, and Dosul Bolătăului, in Hangu commune, Neamț county.

Overall, this toponym is considerably less frequent compared to the previous one due to the fact that it is very seldom used in the contemporary common language. As in the previous case, it is rather difficult to evaluate to what extent and where this toponym is still in use across the Romanian territory without a comprehensive toponimycal inventory of the national territory. However, it appears that the toponym can still be found, particularly in the minor toponymy of the Eastern part of Romania, where the word persists in the everyday language as an archaism.

\subsection{Poland}

Poland is a country in Central Europe which shares common borders with Germany (language belonging to the Germanic group) to the west; the Czech Republic (West Slavic language) and Slovakia (West Slavic language) to the south; Ukraine (East Slavic language), Belarus (East Slavic) and Lithuania (East Slavic) to the east; and the Baltic Sea and Kaliningrad Oblast (East Slavic), a Russian exclave, to the north. The official language of Poland is the Polish language, part of the West Slavic branch of the Slavic languages.

The toponyms which are subject to this study originate in the Polish language from the words "jezioro" and "błoto", which are well known and used in common speech. "Jezioro" is defined as a body of water of considerable size, localized in a basin, that is surrounded by land apart from the sea, while the term "błoto" refers to a very moisturized clay soil forming a dense viscous mass (Skorupko et al., 1969; Szkiłądź et al., 1978).

During the past two decades, artificial reservoirs have also been called "jeziora" (plural; e.g. Jezioro Solińskie, Jezioro Żwieckie); however, according to the professional hydrological terminology, the term "zbiornik" (reservoir) should be used in these instances (i.e. Zbiornik Soliński, Zbiornik Żywiecki).

Considering the fact that the total number of lakes with an area over 1 ha is about 7.100 in Poland (2.200 less than in 1954) (Choiński 2008), it ensues that Jezioro, followed by an adjective or a noun, is the most common toponym in Poland when denominating a lake, in cases such as: Jezioro Śniardwy, Jezioro Gopło, Jezioro Mamry, Jezioro Łebsko, Jezioro Wigry, Jezioro Dużno, Jezioro Skrzynka, Jezioro Tomickie, Jezioro Trzcielińskie, Jezioro Wielkowiejskie, Jezioro Witobelskie, etc.

Most of the aforementioned lakes are located in the Pomeranian Lake District, the Greater Polish Lake District, the Kashubian Lake District and the Masurian Lake District, which are subunits of the North European Plain. The vast majority of these lakes have glacial origins (Scadinavian Ice Sheet, Pleistocene).

A peculiar variation from the ubiquitous use of this toponym when denominating lakes occurs in the case of high altitude lakes located in the Tatra Mountains, the highest part of the Carpathians, which are called "stawy" ("staw"- singular; e.g. Czarny Staw, Zielony Staw, Długi Staw). These lakes have glacial origins (valley glaciers), as well, dating back to the Pleistocene. In the Polish common language, as well as in the hydrological terminology, "staw" is a pond, a manmade body of water designed for fish farming.

Two volumes of the "Słownik geograficzny Królestwa Polskiego i innych krajów słowiańskich" (Geographical Dictionary of the Polish Kingdom and other Slavic countries) $(1880,1882)$ were used as the source of information on toponyms based on "jezioro" (or root "jezior") and "błoto" (or root "błot"). Also, the data presented below refers to the territories contained within the 
previous Polish borders, when the country was under Russian, Austrian and German annexations (Sulimierski et al., 1880; Sulimierski et al., 1882).

A significant number of toponyms containing the root „,jezior" have been inventoried; albeit, they are only partially hydronyms (Sulimierski et al., 1882): lakes Jezierzyce and Jeziorko (2 instances), streams Jezierna (2 instances), Jeziora, Jeziorna, Jezioranka, Jeziorka, Jeziorupa, Jeziornica.

Most of these toponyms denominate elements of the Polish territory, other than lakes or rivers, such as: Jezierce (forestership), Jezierze (village, 2 cases), Jezierki (settlement), Jezierna (small town), Jezierzce (village), Jezierze (village, 2 cases), Jezierzec (village, 2 cases), Jezierzyce (village, 2 cases), Jeziorzyska (farmstead), Jezierzyszcze (village, farmstead), Jezioliszki (yeomen's settlement), Jeziora (village, 3 instances), Jeziorany (town), Jeziorowa (village), Jeziorawka (inn), Jeziorawki (yeomen's settlement), Jeziorce (grange, forestership), Jeziorek (village), Jeziorenki/Jeziorelki (village), Jeziork (village), Jeziorka (village, settlement), Jeziorka (rzeka), Jeziorki/Jeziorken (village, 9 cases; yeomen's settlement; settlement, 2 cases; county; grange, 4 instances; small town; manor, 4 instances; hill), Jeziorodowicze (village), Jeziorody (farmstead), Jeziorossy (or Jeziorowce, city), Jeziorowice (village, 2 cases), Jeziorowskie (village), Jeziorsko/Jeziersko (village), Jeziorszczyzna (yeomen's settlement), Jeziory (village, grange, small town), Jezor (yeomen's settlement), Jeziorki (yeome's settlement; settlement, 2 cases; grange, 3 cases; county, 2 cases; small town, hill), Jeziorko (village, 9 cases; village, 2 cases; grange), Jeziorna (village, 3 times; settlement, 2 times; meadows), Jeziorne (settlement), Jeziorne (or Izerskie or Isergebirge, mountains), Jeziornica (small town), Jeziorny (yeomen's settlement) and Jezioro (village, 3 cases; grange, 2 cases; forestership, settlement).

In the contemporary Polish language, "błoto" refers to mud or to a very moisturized soil (Skorupko et al., 1969; Szkiłądź et al., 1978). As in the case of Slovene, the word "błoto" has become an increasingly archaic name in Polish, as well, and has thus been replaced in the common language by "bagna" (swamp), which is prevalent, and "mokradła" or "moczary" (wetlands), which are used more seldom.

During the previous centuries, "błoto" was used in hydronyms which denominated marshlands, swamps and bogs, and most of the toponyms were created by adding adverbs. However, in the contemporary use, "błoto" has mostly been replaced by the plural form "bagna" or the singular form "bagno", in toponyms such as Bagna Biebrzańskie, Bagna Sredzkie, Bagno Jasieńskie. Toponyms based on "błoto" or root "błot" (combined with adjectives) still remain in use in some cases, particularly in northern Poland, where they denominate swamps, e.g. Błota Kłócieńskie, Bielawskie Błoto, or villages, such as Babie Błota and Białe Błota.

According to "Słownik geograficzny Królestwa Polskiego i innych krajów słowiańskich" (Geographical Dictionary of the Polish Kingdom and other Slavic countries) (1882), toponyms derivative of "błoto" or its root "błot" were most frequently used to denominate villages (18 times, e.g. Błotnowola, Błotków, Błotnia Błotnica, etc.) and settlements (Błota, Błotnik), streams (6 times; e.g. Błotnia, Błoto) and a water channel (Błoto) (Sulimierski et al., 1882).

\subsection{Slovenia}

Slovenia is the westernmost South Slavic speaking country in Europe and has common borders with Italy (language belonging to the Romance group), Austria (Germanic language) and Hungary (language include Hungarian-Finnish groups).

The two toponyms which are subject to our research are relatively common in the Slovenian language and were originally used to denominate two types of landforms, lake ("jezero") and 
marsh ("blato"), respectively. The meaning of the noun "jezero" was traditionally related to larger clean/transparent lakes or reservoirs, while "blato" (meaning mud, wet soil in contemporary Slovenian) commonly refers to a murky, muddy water body (Snoj, 2009).

"Jezero" (lake) is defined as an extended depression in the land, permanently or temporarily filled with still water, and is the exact equivalent of the Romanian "iezer". Moreover, several variations of the word can be found in some Slovenian dialects, such as "jezer" or "jejzer" ("j" in Slovenian language is spelled like " $\mathrm{y}$ " in English).

Throughout the Slovenian territory, the toponym Jezero is most frequently connected to the presence of water bodies (lakes), in instances such as Blejsko jezero and Bohinjsko jezero (glacial lakes), Jezero $v$ Ledvicah, Krnsko jezero, Jezero pod Vršacem (high-mountain lakes, other than glacial), Cerkniško jezero, Palško jezero (intermittent lakes). In a similar manner, reservoirs built on streams often use the word "'jezero" within their name, as in the case of Akumulacijsko jezero Most na Soči". Other types of lakes formed by anthropic intervention, such as collapsed coal mines filled with water, can be denominated in the same manner, as it is the case with Šaleška jezera and Kočevsko jezero.

Overall, according to Atlas Slovenije (2005) which contains topographic maps covering the territory of Slovenia (scale 1: 50 000), the toponym Jezero, in a simple form or as a part of a complex toponym comprising other words (i.e. adjectives or adverbs), can be found in about 200 instances.

Furthermore, the use of the appellative has been expanded over time, so that toponyms including the element "jezero" (or its root "jezer") have come to denominate other elements of the local environment, such as: a) an outlet from a lake (6 times: Jezernica, Jezerščica, Jezerski potok, etc.); b) a permanent settlement located in the vicinity of a lake (18 instances: Jezero, Jezersko, Dolenje jezero, Gorenje jezero, etc.); c) a larger area/region (3 times: Jezera, Jezerska planina, Jezerska dolina); d) a karstic cave (several variations, including Jama Jezero pod Zijalom, Jezerina, jama Jezero, etc.), d) relief elements, including mountains, peaks, saddles (8 instances: Jezerska Kočna, Jezersko sedlo, Jezerski vrh, etc.).

The aforementioned work also inventories 32 examples of toponyms based on "blato" or its root, "blat", in the form of different variations/derivatives, which are used to denominate: a) settlements (18 instances: Blatna Brezovica, Blatna vas, Blatnica, etc.); b) a wider area/area (7 cases: Blatna dolina, Blatni graben, Blatnik, etc.); c) streams (6 times: Blatnica, Blatnik, Blatni potok, etc.); d) karstic caves (several instances, such as Blatno brezno, Blatna jama, Blatnica, etc.) (Atlas Slovenije, 2005).

This toponym is arguably less common today due to the fact that the word "blato" has become increasingly archaic with the evolution of the Slovene language and has been replaced in the language by "močvirje" or "barje", which are today used in a wider range of toponyms.

\subsection{The Czech Republic}

The Czech Republic borders on Germany, Austria, Poland and Slovakia. The Czech language is part of the West Slavic language group which also includes Polish, Slovak, Kashubian and the almost extinct Sorbian. As a consequence of the expulsion of the German population after World War II, the Czech Republic has become a linguistically homogeneous country with several surviving regional dialects especially in the eastern (Moravian and Silesian) part of the country. The lexical preferences of these dialects influence significantly the spatial distribution of geographical names in the Czech territory, including the toponyms under investigation. 
The following analysis is based primarily on the publically available Geonames database maintained by the Czech Office for Surveying, Mapping and Cadastre. It is currently the best source for a large-scale toponymical research in the Czech Republic, because the results of the nation-wide toponymical survey conducted from 1960s to 1980s have still not been published, and although they can be consulted in the archive, village by village, the sheer size of the archive makes it impossible for one person to cover the entire country. No atlas as in the case of Slovenia or geographical dictionary as in the case of Poland contains as detailed information as the Geoname database. The database is certainly incomplete and one if its grave limitations is the standardization of place names which are shown in their official Czech version, not in the local dialect in which the rending of the toponym may be very different, sometimes even with a different meaning. Nevertheless, for the purposes of this article the database provides sufficient material on which to base the toponymical and geographical analysis.

The word "jezero" in Czech is currently used almost exclusively for natural lakes, despite its etymology which is based on the old Czech word "jez" (fence for catching fish) (Holub and Lyer, 1967). The word "jez" is now used for a weir on a river, thus still preserving glimpses of the original meaning of the word. Artificial lakes are referred to either as "přehrada" (dam, reservoir, levy) or "rybník" (pond, usually for pisciculture). Only knowing this etymology can we understand how it is possible to have almost two hundred toponyms derived from the word "jezero" in a country which has only a handful of natural lakes.

To be sure, there are several natural lakes in the Czech Republic - such as the glacial lakes Černé jezero, Jezero Laka, and Plešné jezero (all in the Šumava mountains), peat-bog lakes Mechové jezírko (in the Jeseníky mountains) and Jeřábí jezírko (in the Krušné hory mountains), karst sinkhole lakes such as Macošské jezírko in the karst area Moravský kras or landslide-formed lakes such as Jezero in the Vsetínské vrchy mountains. However, altogether their number does not exceed twenty and we find the word "jezero" more commonly applied to artificial lakes. Most of these toponyms are of recent origin, often dating to the twentieth century, and refer to large ponds, dams, and flooded quarries and surface mines. Examples of these include Máchovo jezero in north-central Bohemia, Jezero Most in northern Bohemia, and Mohelnické jezero in central Moravia. Nevertheless, regardless of the original or current etymology of the word "jezero", the vast majority of place names based on this word does not refer to bodies of water at all, be they natural or artificial. According the the Geonames database, of the roughly 180 entries for a total of 37 toponyms - excluding the aforementioned natural and artificial lakes - only 37 entries refer to bodies of water and 13 to creeks. More commonly, they refer to a strip of agricultural land (67 entries), a strip of forest (23 entries), a settlement (13 entries), a hill (8 entries), a road ( 2 entries) and other objects (a castle, rock cliffs, mountain houses, etc.).

By far, the two most common toponyms based on the word "jezero" are Jezero (62 entries) and Jezera (55 entries). They stand alone for the most part. The other toponyms are significantly less frequent and many occur only once. To mention at least those that appear more than once Jezara ( 2 entries), Jezerce (3 entries), Jezerka (7 entries), Jezerná (4 entries), Jezerné (3 entries), Jezerní hora (2 entries), Jezerní potok (7 entries), Jezernice (2 entries), Jezeř (2 entries), and Jezeři (5 entries). The database unfortunately does register many of the local toponymical variants derived from the root "jezero" such as Jizera, Jezírko, Jizárko, Jizírek, Jezárko, Jezerko and others documented in the nation-wide survey (see e.g. Matúšová, 1995 or Cuřín, 1970).

From a geographical perspective it is interesting to note the spatial distribution of these place names. They concentrate in northwestern, western, central and southern Bohemia and southern Moravia. None or almost none are found in northern, north-eastern, and eastern Bohemia, 
northern and north-eastern Moravia and Silesia. This cannot be explained simply by reference to physical geography, hydrological regimes or the existence of ponds or artificial lakes since the toponyms are absent in regions with low-lying, wet areas with a long history of pisciculture. Rather, dialectal differences should be explored for explaining these regional variations, but an elaboration of this point would well exceed the scope and purpose of this paper.

The situation with the word "blato" is somewhat more complex. The word's etymology refers to a muddy, marshy area (Lutterer and Šrámek, 2004) as in Polish or Slovene, but as is the case with these two languages, for speakers of Czech the word would probably conjur up an image of a wet, muddy marshland but most would never use it actively. Unlike jezero it is now an archaic word and in contemporary Czech we encounter alternative words such as bažina, rašeliniště, močál, mokřina, mokřad and others. A related word bláto is used commonly but only in reference to mud. As will be demonstrated, toponymical material shows that the word "blato" was a wellknown and widely used term in past times.

The Geonames database registers a little over 200 entries for a total of 67 toponyms derived from the root word "blato". It should be noted that while the total number of entries is only slightly higher than that for jezero, the number of toponymical variants is almost twice as large. This is a clear indication of the importance of the word "blato" in the toponymical practice of the historic Slavic populations. It should also be noted that the blato-based toponyms refer three times as often to settlements (including one town) as compared to jezero-based place names.

The most common toponym recorded in the database is Blata (40 entries), followed by Blatiny (15 entries), Blatná (14 entries) Blatnice (14 entries), Blatina (11 entries), and Blato (10 entries). Others mentioned more than once include e.g. Blatec (7 entries), Blatečka (3 entries), Blatenka (2 entries), Blatnička (3 entries), Blatník (5 entries), Blatno (6 entries), Blatný (5 entries) and Blatské (4). As is the case with toponyms based on the word "jezero", blato-based place names refer most often to strips of agricultural land (78 cases), settlements (44 cases), and strips of forests (33 cases). In several instances toponyms also refer to hills, roads, valleys, and castles. Only in 33 cases do they refer explicitly to bodies of water - ponds (17 cases) and creeks (16 cases). In these last two cases the toponym is often not derived from a muddy quality of the pond or the creek but from the name of the settlement to which the pond or the creek belongs.

As in the case of jezero, the geographic distribution of toponyms based on blato is uneven. There is a clear prevalence of blato-base place names in southern Bohemia (52 entries) and an important presence in southern Moravia (24 entries), southeastern Bohemia and southwestern Moravia (21 entries), central Bohemia (21 entries) and central Moravia (19 entries). The northern and eastern part of the country has significantly fewer instances of blato-based toponyms. However, while dialectical differences certainly play role in this case as well, there appears to be a closer association between blato-based place names and permanently wet areas. A testimony to this is the overwhelming presence of blato-based toponyms in southern Bohemia where the original meaning of the word blato remains in everyday usage to this day, denoting marshes, many of them protected under the name Blato as areas of nature conservation. However, the relationship between a toponym and the object it denominates is very complex and further research is needed to uncover the specific genesis of place names for each case 


\section{Conclusions}

The study we conducted in order to document the occurrence and distribution of "iezer"/"jezero"/"jezioro"- and "bolătău"/"blato"/"błoto"-based toponyms in several both Slavicand Romance-speaking countries from throughout Central and South-Eastern Europe (Poland, the Czech Republic, Romania and Slovenia) resulted in several conclusions:

- From a genetic point of view, toponyms lezer and Bolătău in the Romanian language can be considered pseudo-Slavic toponyms; namely, although the nouns from which they derived were of Slavic origin, the toponyms were created by Romanian natives who fully understood the meaning of the words and were able to include and adapt them to their language and further use them for toponymic denomination of various elements of the local environment.

- In the particular case of the toponym lezer (Rom.), which originally designated lakes and reservoirs, we documented that it was later on employed to denominate inlet and outlet streams, and by extension, several other geographical elements, such as mountain peaks (e.g. lezerul Călimanului, in Călimani Mts.), settlements (lezereni village), monasteries (lezeru, Vâlcea) etc. Currently, the name lezer, sometimes followed by a determiner (e.g. lezerul Latoriței, Parâng Mts.) is also particularly frequent in the case of high altitude glacial lakes located in the Romanian Carpathians (i.e. 8,1\% of 161 glacial lakes).

Both toponyms, in the form of various derivatives of the roots and/or combinations with determiners, are used in a wide range of instances and are not limited solely to a specific form of the landscape, albeit they were originally used as limnonyms. Our research shows that toponyms derived from the roots "iezer"/"jezero"/"jezioro", and "bolătău"/"blato"/ "błoto", respectively, have broadened their scope so as to denominate streams, permanent or temporary settlements, elements of the relief, patches of land of various sizes and land uses, administrative units, etc., aside from lakes and reservoirs.

- As regards the extent to which the current presence of both toponyms is linked to the occurrence of the hydrological features they originally denominated, our results appear to indicate that "iezer"/"jezero"/"jezioro"- and "bolătău"/"blato"/"błoto"-based current toponyms are seldom good predictors of the actual occurrence of lakes and/or reservoirs and related geomorphological features (lake basins etc.). Regardless of the original or current etymology of the words, most of the toponyms inventoried throughout the entire study area do not refer to water bodies at all, either lakes, reservoirs or streams. A likely explanation could be based on the fact that the toponyms denominated man-made lakes or ponds and marshes, which were rather frequent in the past, but mostly ephemeral. Albeit, the toponyms survived and extended to other present-day features (settlements, rivers, forests, strips of land etc).

- As regards the current distribution and frequency in use of the respective toponyms throughout the study area, whereas in Slovenia, the Czech Republic and Poland both terms, and especially "jezero"/"jezioro", are still in use in the current vocabulary, in Romania both appellatives have become rather archaic terms, and are thus more prone to being replaced in the contemporary and future toponymy. 


\section{References}

Buză M., Badea L., Dragomirescu Ş. (coord.). 2008. Dicţionarul geografic al României, vol. I, A-L. Ed. Academiei Române, București.

Choiński A. 2008. Jeziora w parkach narodowych, rezerwatach przyrody i w parkch krajobrazowych [w:] J. Partyka, J. Pociask-Karteczka, red. Wody na obszarach chronionych, IGiGP UJ, OPN, KOPTG, Kraków, 31-43 (Lakes in national parks, nature reserves and landscape parks).

Conedera M., Vassere S., Neff C., Meurer M., Krebs P. 2007. Using Toponymy to Reconstruct Past Land Use: A Case Study of 'Brusada' (Burn) in Southern Switzerland. Journal of Historical Geography 33: 729-748.

Cuřín F. 1970. Kapitoly z dějin českých nárečí a mistních a pomístních jmen. Univerzita Karlova, Praha.

Farcas S., de Beaulieu J.S., Reille M., Coldea G., Diaconeasa B., Goeury C., Goslar T., Jull T. 1999. First $14 \mathrm{C}$ datings of Late Glacial and Holocene pollen sequences from Romanian Carpathes. Population biology 322: 799-807.

Feurdean A., Wohlfarth B., Björkman L., Tantau I., Bennike O., Willis K.J., Farcas S., Robertsson A.M. 2007. The influence of refugial population on Lateglacial and early Holocene vegetational changes in Romania. Review of Paleobotany and Palynology 145 (2007): 305320.

Feurdean A., Tămaș T., Tanțău I., Fărcaș S. 2012. Elevational varioation in regional vegetation responses to late-glacial climate changes in the Carpathians. Journal of Biogeography 39: 258-271.

Ghinea D. 1996. Enciclopedia geografică a României, vol. I. Ed. Enciclopedică, București.

Grămadă N. 1996. Toponimia minoră a Bucovinei I și II. Ed. Anima, Bucureşti.

Holub J. \& Lyer S. 1967. Stručný etymologický slovník jazyka českého. Státní pedagogické nakladatelství, Praha.

Iordan I. 1963. Toponimia românească. Ed. Academiei, București.

losep I. 1995. Un fenomen inedit: transhumanţa câmpulungeană. Codrul Cosminului, seria nouă, 1/1995. Fundaţia Culturală a Bucovinei, Suceava.

losep I. 1996. Ocolul Câmpulungului Moldovenesc în secolele XVII -XVIII. Reconstituire după izvoare documentare, toponimice şi cartografice, Codrul Cosminului, seria nouă, 2/1996. Univ. "Ştefan cel Mare”, Suceava.

Lesenciuc C.-D., Mihu-Pintilie A., Nicu I.-C., Condorachi D. 2010. Caracteristici geomorfologice ale lacului lezer din Obcina Feredeului. In Volumul Simpozionului Național "Resursele de apă. Vulnerabilitate la presiunea activităților antropice cu referire și la ecosistemele lacustre". Târgoviște: 283-288.

Lutterer I. \& Šrámek R. 2004. Zeměpisná jména v Čechách, na Moravě a ve Slezsku. Tobiáš, Havlíčkův Brod.

Matúšová J. 1995. Hláskosloví pomístních jmen. In Olivová-Nezbedová, L. et al. Pomístní jména v Čechách. O čem vypovídají jména polí, luk, lesủ, hor, vod a cest. Academia, Praha: 81-142. 
Mîndrescu M., Iosep I., Cristea I.A., Forgaci D., Popescu D.A. 2010a. Lacurile lezer și Bolătău (Obcina Feredeului) - cele mai vechi lacuri de baraj natural formate prin alunecare din Romania. In Volumul Simpozionului Național "Resursele de apă. Vulnerabilitate la presiunea activităților antropice cu referire și la ecosistemele lacustre". Târgoviște: 272-282.

Mîndrescu M., Cristea A.I., Florescu G. 2010b. Water quality and ecology of the lezer and Bolătău lakes. Lakes reservoirs and ponds. Romanian Journal of Limnology 4 (1-2): 117-130.

Mîndrescu M., Cristea A.I., Hutchinson S.M., Florescu G., Feurdean A. 2012. Interdisciplinary investigations of the first reported laminated lacustrine sediments in Romania. Quaternary International, doi:10.1016/j.quaint.2012.08.2105.

Moldovanu D. 2005. Tezaurul toponimic al Moldovei. Vol. I, Partea a 4-a. Toponimia Moldovei in cartografia europeană veche (cca 1395-1789). Ed. Univ. Al. I. Cuza, Iași.

Posea Gr. (coord.), Barbu N., Ciulache S., Posea Aurora, Nicolae I., Ștefănescu loana, Vespremeanu E., Giurescu M. 1986. Geografia de la A la Z. Dicționar de termeni geografici. Ed. Științifică și Enciclopedică, București.

Scriban A. 1939. Dicționaru limbiŭ româneștĭ (Etimologii, înțelesuri, exemple, citațiuni, arhaizme, neologizme, provincialisme). Ed. "Presa Bună", Iași.

Skorupko S., Audrerska H., Łempicka Z. (red.). 1969. Mały słownik języka polskiego, T. 1. PWN, Warszawa, 1034. (Small dictionary of Polish language).

Snoj M. 2009. Slovenski etimološki Slovar (2nd edition). Modrijan, Ljubljana, 1022.

Sulimierski F., Chlebowski B., Walewski W. 1880. Słownik geograficzny Królestwa Polskiego i innych krajów słowiańskich, T. I. Wydany Pod Reakcją Wędrowiec. Warszawa, Druk „WIEKU” Nowy Świat. (Geographical Dictionary of the Polish Kingdom and other Slavic countries).

Sulimierski F., Chlebowski B., Walewski W. 1882. Słownik geograficzny Królestwa Polskiego i innych krajów słowiańskich, T. V. Wydany Pod Reakcją Wędrowiec. Warszawa, Druk „WIEKU” Nowy Świat. (Geographical Dictionary of the Polish Kingdom and other Slavic countries).

Szkiłądź H., Bik S., Szkiłądź C. (red.). 1978. Słownik języka polskiego, T. 1. PWN, Warszawa, 1103. (Dictionary of Polish language).

Ştefanelli T.V. 1915. Documente din vechiul ocol al Cîmpulungului Moldovenesc. Bucureşti.

***Atlas Slovenije 1:50000. 2005. Mladinska knjiga Založba, Ljubljana: 487.

***Atlasul Cadastrului Apelor din R. P. Română, C.S.A., vol. I-IV. 1964, 1968, 1970, 1972. Bucureşti.

***Geonames. Czech Office for Surveying, Mapping and Cadastre. http://geoportal.cuzk.cz.

***Dicționarul explicativ al limbii române, Ediția a II-a. 1998. Academia Română, Institutul de Lingvistică „lorgu Iordan”, Editura Univers Enciclopedic, București.

***Documente privind Istoria României (D.I.R). Veacurile XIV şi XV, Seria A. Moldova, vol. I, 13841475. 1954. Ed. Academiei R.P.R., Bucureşti.

***Documente privind Istoria României (D.I.R). Veacul XVI, Seria A. Moldova, vol. IV, 1591-1600. 1952. Ed. Academiei R.P.R., Bucureşti. 